\title{
Effect of gonadectomy on epidermal growth factor values in the gastrointestinal tract of male and female CD-1 mice
}

\author{
M Sayegh, J B Elder
}

\begin{abstract}
The effects of gonadectomy on the epidermal growth factor (EGF) concentrations in the gastrointestinal tract of CD-1 mice were studied. The EGF concentrations in the gastrointestinal tissues were always higher in males than in females. Gonadectomy led to a decrease in the EGF concentration in males, and an increase in females. Gonadectomy with sialoadenectomy led to a decrease in the EGF concentrations in the gastrointestinal tract of both sexes; the most significant effect being observed in the stomach. Orchidectomy led to a decrease in total body weight, and to a significant decrease in the weight and the protein concentration (ng. - $^{-1}$ wet weight of tissue) of the submandibular gland, but had no significant effect on the other tissues of the gastrointestinal tract of male mice. Body, tissue weights, and protein concentrations did not change with oophorectomy. This study shows that male and female gonads have a profound effect on the EGF content of the tissues of the gastrointestinal tract and suggests that the submandibular gland also influences the EGF concentration in gastrointestinal tissues in mice.

(Gut 1995; 36: 558-563)
\end{abstract}

Keywords: epidermal growth factor, gonadectomy, gastrointestinal tract, mice.

It is well established that endocrine glands and their hormonal secretions may play a major part in synthesis, secretion, release, and regulation of epidermal growth factor (EGF). ${ }^{1-5}$ Studies in the mouse suggest that the EGF concentration in the submandibular gland is influenced by androgens, progesterone, oestrogen, and thyroid hormones, possibly by effecting the synthesis of prepro-EGF. ${ }^{1-5}$ It is yet to be determined if the gut itself is a target organ for these hormones with regard to EGF synthesis. The concentration of EGF in the submandibular salivary gland is dependent on the sexual maturity of the mouse; it increases after puberty and is also androgen dependent. ${ }^{36}$ The stimulatory effects of androgen and thyroxin $\left(T_{4}\right)$ on the EGF concentration in the submandibular gland have been reported. ${ }^{3}$ The multiple effects of sex steroids on the EGF concentration vary throughout body fluids and organs. ${ }^{28}$ They are probably mediated through modulation of EGF's gene activity. Streidler and Reade $^{9}$ studied the submandibular gland histologically in orchidectomised mice, with and without hormonal replacement, and observed the reversible atrophic changes of the submandibular gland alone, and its EGF content after administration of testosterone. Oestradiol has been reported to have either an increasing or decreasing effect, or no effect, while testosterone has no decreasing effects. Testosterone has been shown to increase the EGF concentration in mouse plasma and the submandibular gland, while 17- $\beta$ oestradiol causes an increase in the EGF in male urine and in the plasma of sialoadenectomised female mice. It has been suggested that EGF synthesis and storage are stimulated by androgens, but not EGF release from the submandibular gland, since the EGF concentration in this gland does not parallel basal plasma and urine concentrations. ${ }^{89}$

In this study we investigated the effect of gonadectomy on the EGF concentration in the gastrointestinal tract of male and female mice. EGF concentrations were measured four weeks after surgery had been performed in seven week old sexually mature mice and were compared with values in sham operated controls.

\section{Methods}

PREPARATION OF EGF EXTRACTS

Extracts of EGF were obtained using a method developed by Gregory and Willshire (ICI, Alderly Edge, England, personal communication). Tissues $(6 \mathrm{~g})$ were placed in $40 \mathrm{ml}$ of extraction buffer precooled in ice and blended at high speed using a homogeniser three times for 15 seconds to minimise foaming and shearing, with an ice bath immersion between blends. The extraction buffer was $20 \mathrm{mM}$ HEPES buffer $\mathrm{pH} 7 \cdot 4$, contained $1 \mathrm{mM}$ ethylene diamine tetra acetic acid (EDTA) $1 \mathrm{mM}$ ethylene glycol bis ( $\beta$-amino ethyl ether) NNN tetra acetic acid (EGTA), and $0.5 \mathrm{mM}$ phenyl methyl sulphonyl fluoride (PMSF). The homogenate was centrifuged at $1700 \mathrm{rpm}$ $(800 \mathrm{~g})$ for 15 minutes at $4^{\circ} \mathrm{C}$. The resulting supernatant was then centrifuged $(40000 \mathrm{~g})$ for one hour at $4^{\circ} \mathrm{C}$. It was decanted into absolute ethanol (two volumes), shaken, and recentrifuged $(3000 \mathrm{~g})$ for one hour at $4^{\circ} \mathrm{C}$. The supernatant was decanted into four volumes of cold ethyl acetate and the opalescent mixture allowed to stand at $4^{\circ} \mathrm{C}$ for 16 hours. The organic phase was gently decanted and discarded, leaving a thin 
aqueous layer which was then washed into a round bottomed flask with between 1 and $5 \mathrm{ml}$ of $0.1 \mathrm{M}$ acetic acid. This solution can then be freeze dried for further studies.

\section{PROTEIN ASSAY}

Protein concentrations were determined by the method of Bradford with bovine $\gamma$ globulin as standard. ${ }^{10}$

IODINATION AND RADIOIMMUNOASSAY OF EGF Iodobeads were obtained from the Pierce Chemical Company, USA. Standard EGF was obtained from the Sigma Chemical Co (Poole, Dorset, England). Rabbit anti-mEGF antibody was kindly donated by Dr H Gregory (ICI Ltd, Alderley Park, Macclesfield, England). Sac-Cel, solid phase 2nd antibody (donkey anti-rabbit) coated cellulose suspension, was obtained from IDS Ltd (Boldon, Tyne \& Wear, England). ${ }^{125}$ I and standard mouse EGF (mEGF) were obtained from Amersham International (Amersham, England).

\section{Iodination protocol}

The standard assay buffer was $0.04 \mathrm{M}$ phosphate buffer $\mathrm{pH} 7 \cdot 2$, containing $0.15 \mathrm{M}$ sodium chloride, $0.01 \mathrm{M}$ sodium azide, and $0.5 \%$ BSA. Mouse EGF was iodinated by the iodobead method using freshly prepared buffers. The iodobead was prewashed with $0 \cdot 1 \mathrm{M}$ phosphate buffer $\mathrm{pH} 8.1$ and placed in a small Durham tube (Fisons) containing $100 \mu \mathrm{l}$ of the same buffer. One $\mu \mathrm{g}(0.16 \mathrm{nmol})$ of m-EGF (Sigma, 95\% pure) and $500 \mu \mathrm{Ci}(0.25$ nmol) of $\mathrm{Na}^{125}$ I were added and the contents of the tube were incubated for 15 minutes at room temperature with gentle mixing. Some $100 \mu \mathrm{l}$ of the assay buffer was added to stop the reaction and the resultant mixture was immediately applied to a Sephadex G-25 gel

TABLE I Extraction data for control, sham operated, and orchidectomised mice (submandibular gland, stomach, small intestine, and colon)

\begin{tabular}{|c|c|c|c|c|c|}
\hline Tissue & $\begin{array}{l}\text { Total } \\
\text { EGF } \\
\text { (ng) }\end{array}$ & $\begin{array}{l}\text { Total } \\
\text { protein } \\
\text { (mg) }\end{array}$ & $\begin{array}{l}\text { Tissue } \\
\text { wet wt } \\
\text { (g) }\end{array}$ & $\begin{array}{l}\text { Protein } \\
\text { (mg/g wet } \\
\text { wt tissue) }\end{array}$ & $\begin{array}{l}E G F \\
\text { (ng/g wet } \\
\text { wt tissue) }\end{array}$ \\
\hline \multicolumn{6}{|l|}{ Male controls 7 wk: } \\
\hline Submandibular gland & 68800 & $5 \cdot 2$ & 1.28 & $4 \cdot 06$ & 53750 \\
\hline $\begin{array}{l}\text { Stomach } \\
\text { Small intestine }\end{array}$ & $\begin{array}{r}1050 \\
840\end{array}$ & $\begin{array}{l}0.91 \\
2 \cdot 33\end{array}$ & $\begin{array}{l}1.56 \\
8.01\end{array}$ & $\begin{array}{l}0.58 \\
0.29\end{array}$ & $\begin{array}{l}670 \\
105\end{array}$ \\
\hline Colon & 740 & $1 \cdot 17$ & $2 \cdot 82$ & 0.414 & 260 \\
\hline \multicolumn{6}{|l|}{ Male controls $11 \mathrm{wk}$ : } \\
\hline Submandibular gland & 108750 & $7 \cdot 5$ & 1.61 & $4 \cdot 658$ & 67500 \\
\hline Stomach & 1125 & 1.08 & 1.6 & 0.675 & 700 \\
\hline Small intestine & 730 & $2 \cdot 35$ & $7 \cdot 5$ & $0 \cdot 313$ & 100 \\
\hline $\begin{array}{l}\text { Colon } \\
\text { Male sham operated. }\end{array}$ & \multicolumn{2}{|c|}{ Male sham operated: } & $3 \cdot 7$ & 0.34 & 200 \\
\hline Submandibular gland & 93520 & $8 \cdot 4$ & 1.58 & $5 \cdot 316$ & 59190 \\
\hline Stomach & 1020 & 1.43 & 1.61 & $0 \cdot 888$ & 630 \\
\hline Small intestine & 1133 & $4 \cdot 13$ & 7.9 & 0.52 & 143 \\
\hline Colon & 640 & 1.635 & $3 \cdot 3$ & 0.495 & 195 \\
\hline \multicolumn{6}{|l|}{ Male orchidectomised: } \\
\hline Submandibular gland & 3890 & $2 \cdot 04$ & 1.07 & 1.906 & 3635 \\
\hline Stomach & 540 & $1 \cdot 15$ & 1.52 & 0.756 & 356 \\
\hline Small intestine & 458 & $2 \cdot 62$ & $7 \cdot 2$ & 0.36 & 63 \\
\hline Colon & 84 & 1.77 & $3 \cdot \overline{1}$ & 0.57 & 27 \\
\hline \multicolumn{6}{|c|}{ Male orchidectomised and sialodectomised: } \\
\hline Stomach & 21 & $0 \cdot 32$ & 1.61 & $0 \cdot 198$ & 13 \\
\hline Small intestine & 111 & 1.87 & 6.9 & $0 \cdot 27$ & 16 \\
\hline Colon & 50 & $2 \cdot 28$ & $2 \cdot 63$ & 0.864 & 19 \\
\hline
\end{tabular}

$\mathrm{EGF}=$ epidermal growth factor. filtration column (Pharmacia PD-10, $10 \times 0.5$ cm) pre-equilibrated with $25 \mathrm{ml}$ of $0.04 \mathrm{M}$ phosphate buffer pH $7 \cdot 2$ containing $0.5 \%$ BSA. Fractions $(500 \mu \mathrm{l})$ were collected at room temperature. The iodinated EGF was stored at $4^{\circ} \mathrm{C}$ for not more than two weeks.

\section{Radioimmunoassay of $m-E G F$}

A series of EGF standards in the range 0.19-100 ng were made. Each assay tube was prepared by adding a $250 \mu \mathrm{l}$ sample (standard or test) and $250 \mu \mathrm{l}^{125} \mathrm{I}-\mathrm{EGF}$ at a concentration of 80 to $100 \mathrm{pg}$ to give 25000 total CPM/tube. Then $250 \mu \mathrm{l}$ of anti-EGF antibody was added to all the tubes except the blank and totals (tracer, iodinated EGF only). The EGF antibody was diluted to $1: 120000$ in $0.04 \mathrm{M}$ phosphate buffer pH $7 \cdot 2$. The tubes were mixed and incubated for $36-40$ hours at $4^{\circ} \mathrm{C}$. Then $100 \mu l$ of donkey anti-rabbit globulin Sac-Cel were added to all tubes (except the totals), mixed, and left for 30 minutes at room temperature. Water $(1 \mathrm{ml})$ was added before a 10 minute centrifugation at $5000 \mathrm{~g}$ at $4^{\circ} \mathrm{C}$. Centrifugation led to the separation of the supernatant, which was aspirated from all tubes (except the totals), and the radioactivity of the precipitate was measured over 60 seconds using an LKB auto- $\gamma$ counter. The non-specific binding was subtracted from all results which were then expressed as a percentage of the total binding.

\section{EXPERIMENTAL PROCEDURE}

Mice were obtained from Charles Rivers Company (CD-1). Adult male mice weighing between 36.4 and $42.7 \mathrm{~g}$ and adult female mice weighing between 26.7 and $32.2 \mathrm{~g}$ were used. Mice were housed under controlled conditions of lighting $(14 \mathrm{~h} / \mathrm{d})$, with an intensity of 300 lux, humidity was $55 \% \pm 5 \%$, and temperature $21 \pm 2^{\circ} \mathrm{C}$. Animals were freely fed on a $41 \mathrm{~B}$ diet (Pilsburg, UK) and water. The animals were randomly divided into five groups of six mice for each sex. The experiment was performed twice. The groups were as follows: (1) control 7 weeks old, (2) control 11 weeks old, (3) sham 11 weeks old, operated at 7 weeks, (4) gonadectomised 11 weeks old, operated at 7 weeks, (5) gonadectomised and sialoadenectomised 11 weeks old, operated at 7 weeks. Gonadectomy and gonadectomy with sialoadenectomy were performed at the age of 7 weeks by which time all the mice had reached sexual maturity. The animals were sacrificed 4 weeks later, however, because it had been reported that the EGF concentration in the submandibular gland after oophorectomy reached a plateau within four to six weeks. ${ }^{512}$

\section{Anaesthesia and surgical procedure}

The animals were put on special heating pads during the surgical procedure. Anaesthesia was induced with $3 \%$ halothane and maintained with $1-1.5 \%$ halothane in addition to $55 \%$ nitrous oxide, $1 \%$ carbon dioxide, and the balance made up of oxygen. 
TABLE II Extraction data for control, sham operated, and oophorectomised mice (submandibular gland, stomach, small intestine, and colon)

\begin{tabular}{|c|c|c|c|c|c|}
\hline Tissue & $\begin{array}{l}\text { Total } \\
\text { EGF } \\
\text { (ng) }\end{array}$ & $\begin{array}{l}\text { Total } \\
\text { protein } \\
\text { (mg) }\end{array}$ & $\begin{array}{l}\text { Tissue } \\
\text { wet wt } \\
\text { (g) }\end{array}$ & $\begin{array}{l}\text { Protein } \\
\text { ( } m g / g \text { wet } \\
\text { wt tissue) }\end{array}$ & $\begin{array}{l}E G F \\
\text { (ng/g wet } \\
\text { wt tissue) }\end{array}$ \\
\hline \multicolumn{6}{|l|}{ Female controls 7 wk: } \\
\hline Submandibular gland & 3547 & $1 \cdot 72$ & $1 \cdot 11$ & 1.549 & 3196 \\
\hline Stomach & 54 & $0 \cdot 3$ & 1.64 & $0 \cdot 183$ & 33 \\
\hline Small intestine & 165 & 1.599 & $8 \cdot 13$ & $0 \cdot 196$ & 20 \\
\hline Colon & 49 & $1 \cdot 35$ & $3 \cdot 50$ & 0.385 & \\
\hline \multicolumn{6}{|l|}{ Female controls $11 \mathrm{wk}$ : } \\
\hline Submandibular gland & 3270 & 1.98 & $1 \cdot 2$ & 1.65 & 2725 \\
\hline Stomach & 96 & 0.48 & $1 \cdot 6$ & $0 \cdot 30$ & 60 \\
\hline Small intestine & 123 & $2 \cdot 975$ & $8 \cdot 1$ & 0.36 & 15 \\
\hline Colon & 45 & $1 \cdot 26$ & $3 \cdot 0$ & 0.42 & 15 \\
\hline \multicolumn{6}{|l|}{ Female shame $11 \mathrm{wk}$ : } \\
\hline Submandibular gland & 3486 & $2 \cdot 16$ & 1.25 & 1.728 & 2780 \\
\hline Stomach & 69 & 0.45 & $1 \cdot 83$ & 0.245 & 37 \\
\hline Small intestine & 116 & $5 \cdot 67$ & $8 \cdot 5$ & 0.667 & $13 \cdot 6$ \\
\hline Colon & 42 & $1 \cdot 23$ & $3 \cdot 3$ & 0.37 & $12 \cdot 8$ \\
\hline \multicolumn{6}{|l|}{ Female oophorectomised: } \\
\hline Submandibular gland & 15158 & $2 \cdot 12$ & $1 \cdot 1$ & 1.927 & 13780 \\
\hline Stomach & 500 & 0.405 & 1.67 & $0 \cdot 24$ & 299 \\
\hline Small intestine & 135 & $2 \cdot 268$ & $6 \cdot 8$ & 0.33 & 20 \\
\hline Colon & 90 & $1 \cdot 8$ & $3 \cdot 25$ & 0.55 & $28 \cdot 8$ \\
\hline \multicolumn{6}{|c|}{ Female oophorectomised and sialodectomised: } \\
\hline Stomach & 36 & 0.4 & 1.56 & $0 \cdot 256$ & 23 \\
\hline Small intestine & 30 & $2 \cdot 1$ & $7 \cdot 86$ & $0 \cdot 267$ & 4 \\
\hline Colon & 7 & $1 \cdot 4$ & 2.98 & 0.469 & $2 \cdot 2$ \\
\hline
\end{tabular}

Orchidectomy and the sham groups were placed on their dorsal surface, and a midline incision was made in the scrotum. Oophorectomy was carried out by placing the animals on their ventral surface, and a mid-line incision was made in the dorsal region where the ovaries were easily identified and removed. Sialoadenectomy was undertaken by removal of the submaxillary glands following a V-shape incision in the submandibular region.

After gonadectomy, the mice were weighed daily for the first week and every week for the next three weeks. The reason for choosing two control groups was to rule out any spontaneous growth related changes which might take place during the four week period after gonadectomy.

\section{Sample preparation and EGF measurement}

The animals were sacrificed by $\mathrm{CO}_{2}$ narcosis and cervical dislocation. The tissues were removed, cleaned from food and faecal residues, and weighed as a pool for each group of animals $(n=6)$, before extraction and assay. The extracts were serially diluted and were assayed in duplicate at four dilutions. For the measurement of assay precision and reproducibility, the effect of interassay variability was determined and the effect of dilution on the estimates of the original pooled extracts was assessed. The duplicate assays agreed within $10 \%$ of each other.

\section{STATISTICAL ANALYSIS}

A non-parametric analysis (Mann-Whitney U test) was performed in the analysis of the EGF data using the Number Cruncher Statistical system software (NCSS, Version 5.7). The data are presented as mean (SEM) unless otherwise stated. A one way analysis of variance using Microstat software was employed for the determination of the difference in tissue and total body weight after gonadectomy; $\mathrm{p}<0.05$ was considered to be significant.
We determined the effect of gonadectomy on the weight of the animal and tissue, protein concentration and EGF yield.

\section{Results}

EFFECT OF GONADECTOMY ON THE PROTEIN YIELD

The protein concentration per wet weight tissue $(\mathrm{mg} / \mathrm{g})$ was determined in all tissues of each group for both sexes and the results are shown in Tables I and II. Gonadectomy resulted in a significant decrease in the protein content of the male submandibular gland only (64\% v sham, $59 \% v 11$ week control, and $53 \%$ decrease $v$ the 7 week control, $\mathrm{p}<0.02$ ); furthermore gonadectomy with sialoadenectomy caused a significant decrease in protein concentration in the male stomach alone $(\mathrm{p}<0.05)$.

Orchidectomy and orchidectomy plus sialoadenectomy resulted in appreciable increases in protein content of $67 \%$ and $154 \%$ respectively in the colon $(p<0.02)$ compared with the 11 week controls.

EFFECT OF GONADECTOMY ON TISSUE WEIGHT Orchidectomy led to a decrease in the weight of the submandibular gland compared with the control groups (230 (20) v 300 (12) mg; $\mathrm{p}<0 \cdot 01)$ ), but there was no significant effect of orchidectomy with and without sialoadenectomy upon the weights of the stomach and colon. A small decrease in weight of the small intestine was seen after orchidectomy with sialoadenectomy compared with values in the control groups (1170 (20) v 1220 (50 mg), but this did not reach significance. Oophorectomy with or without sialoadenectomy caused no significant change in the weight of any of the tissues studied.

EFFECT OF GONADECTOMY ON TOTAL BODY WEIGHT

Both orchidectomy (TBW 35.16 (0.35) g) and orchidectomy with sialoadenectomy (TBW

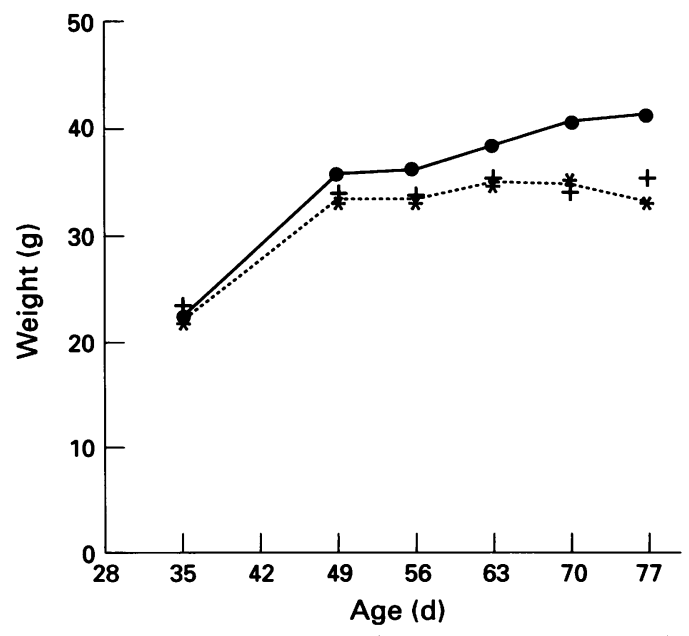

Figure 1: Comparison between sham operation (- $\bullet$-) and orchidectomy (with $(-+-)$ and without $\left({ }^{\star}{ }_{-}\right)$ sialoadenectomy) on the weight gain in male CD-1 mice. 

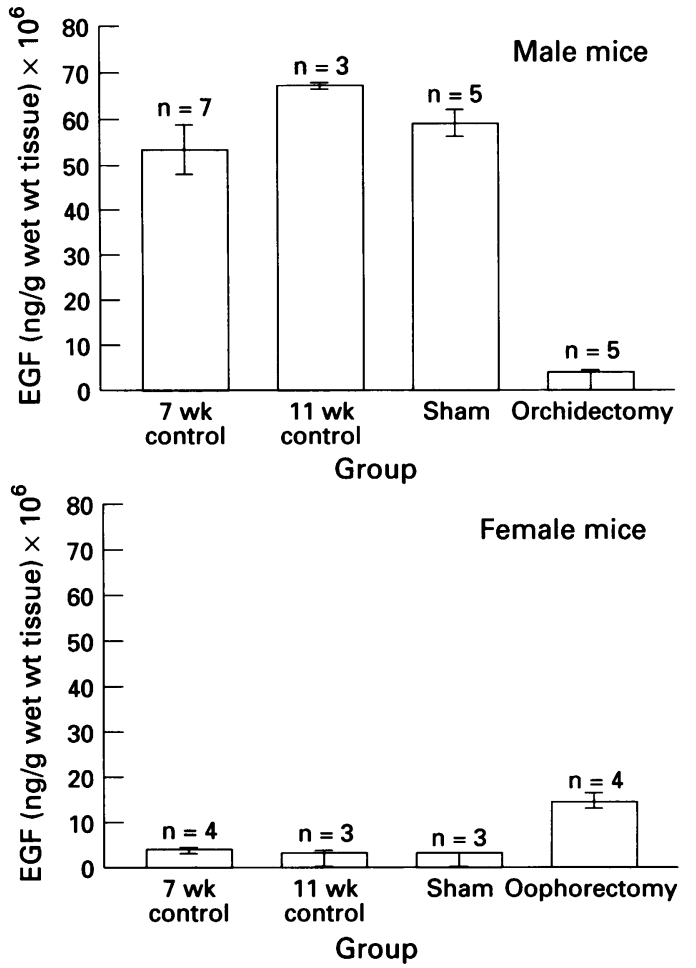

Figure 2: Epidermal growth factor (EGF) concentrations in submandibular gland tissue from male and female mice ( $n=$ number of animals studied).

$32.91(0.88) \mathrm{g})$ resulted in a net decrease in body weight $(\mathrm{p}<0.001)$ when compared with controls $(38.6(0.98) \mathrm{g})$ and sham operated (40.95 (1) g) groups (Fig 1). In female mice, oophorectomy with and without sialoadenectomy did not result in any significant change in body weight.

\section{EFFECT OF GONADECTOMY ON THE EGF} CONCENTRATION IN THE GASTROINTESTINAL TRACT

The effects of gonadectomy with or without sialoadenectomy upon the EGF concentration (ng/g wet weight tissue), specific activity ( $\mu \mathrm{g}$ $\mathrm{EGF} / \mathrm{mg}$ protein), and total EGF in the submandibular gland, stomach, small intestine, and colon of all the groups of mice are shown in Tables I and II. Figures 2 to 5 compare EGF concentrations in ng/g net weight of tissue. The EGF concentration in all male tissues decreased after orchidectomy - by 17 fold in the submandibular gland $(p<0.005)$; twofold in the stomach $(p<0.005) ; 1.7$ fold in the small intestine $(p<0.05)$; and eightfold in the colon $(p<0.005)$. Orchidectomy with sialoadenectomy resulted in a 50 fold decrease in the EGF concentration per wet weight stomach tissue $(p<0.0002)$, a seven fold decrease in small intestine $(p<0.02)$, and an eightfold decrease in the EGF concentration of the colon compared with values in the control and sham operated groups $(p<0.005)$. Oophorectomy resulted in an increase in the EGF concentration in the submandibular gland (fivefold $p<0.02$ ), stomach (sevenfold $\mathrm{p}<0.02$ ), small intestine (insignificant effect), and colon (twofold $\mathrm{p}<0.05)$ compared with values in the control and sham operated groups. On the other hand,

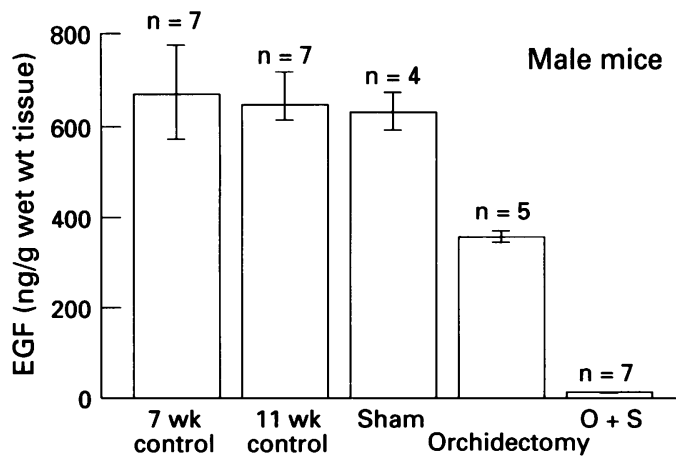

Group

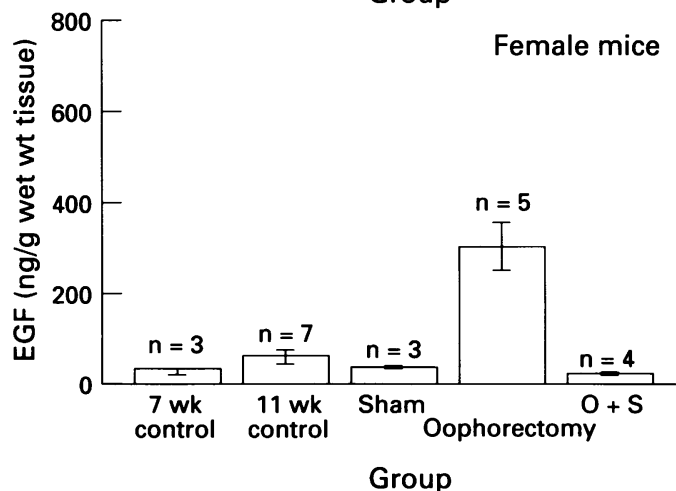

Figure 3: Epidermal growth factor (EGF) concentrations in stomach tissue from male and female mice.

$O+S=$ orchidectomy/oophorectomy+sialoadenectomy.

oophorectomy and sialoadenectomy resulted in an approximately twofold decrease in the stomach EGF concentration $(p<0.05)$, a fourfold decrease in the small intestine $(p<0.007)$, and a 6.5 fold decrease in the colon compared with values in the control and sham operated groups $(p<0.04)$.

There was approximately 20 times more immunoreactive EGF in the submandibular gland of the male mice than the female
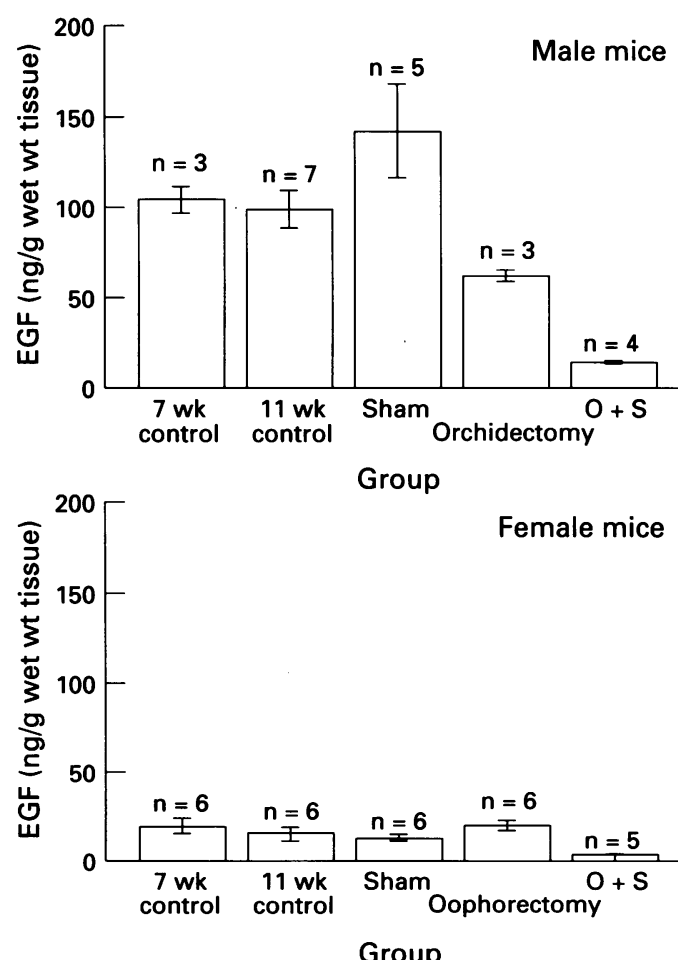

Figure 4: Epidermal growth factor (EGF) concentrations in small intestinal tissue from male and female mice. $O+S=$ orchidectomy/oophorectomy + sialoadenectomy. 

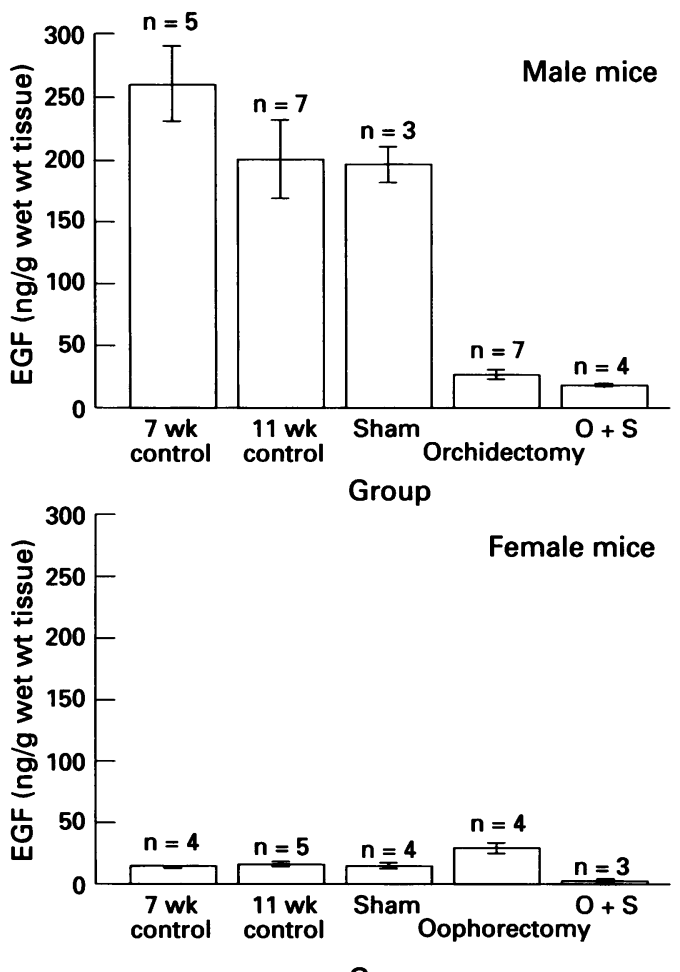

Group

Figure 5: Epidermal growth factor (EGF) concentrations in colonic tissue from male and female mice.

$O+S=$ orchidectomy/oophorectomy + sialoadenectomy.

mice in the control and sham operated groups $(p<0.02)$. Gonadectomy reversed this relationship with respect to the EGF concentration, however, which was five times greater in the submandibular gland of the female mice than in the male animals $(p<0.02)$. There is approximately 15 times more EGF in the stomach of male mice compared with female mice in the 11 week control group $(p<0.002)$, but gonadectomy resulted in a similar EGF concentration for both sexes. However, gonadectomy and sialoadenectomy of both sexes led to significant decreases in the EGF concentrations - 50 fold and twofold in male and female mice respectively - compared with the values in the control and sham groups (Fig 3). The resulting difference between the sexes was small, yet still significant $(p<0.01)$.

In the small intestine the sex difference was once again apparent. There was a five to 10 fold greater EGF concentration in the male than the female mice $(p<0.005)$ in the 11 week male and female sham groups (145 ng/g wet weight $v \quad 13.6 \mathrm{ng} / \mathrm{g}$ ) (Fig 4). Although orchidectomy led to a $50 \%$ fall in the EGF concentration in the small intestine, there was no measurable effect with oophorectomy. The orchidectomised mice had a threefold greater concentration of EGF in the small intestine than the oophorectomised mice $(p<0.02)$. Furthermore, sialoadenectomy with gonadectomy led to a fourfold greater concentration of $E G F$ in the small intestine of male mice than female mice $(p<0 \cdot 02)$.

The immunoreactive EGF concentration in the colon was 13 times greater in male than in female 11 week control animals and 17 times greater for the sham groups $(p<0.01)$, but after gonadectomy the sex difference was not as great (Fig 5). Sialoadenectomy with gonadectomy led to an 8.6 times as much EGF in the male colon than in the female colon (Fig 5, p<0.01).

\section{Discussion}

The results clearly show that before gonadectomy the EGF concentrations in the submandibular gland and other tissues of the gastrointestinal tract of male mice are always higher than in the female (Figs 2 to 5). This finding agrees with the results of other workers who showed significant differences in the submandibular gland EGF concentrations between the sexes. This could be due to several factors. These include variability in the method of assay or the use of different forms of EGF, including its precursor form, which could give rise to different yields during the extraction procedure. Gonadectomy led to a decrease in the EGF concentration in all male gastrointestinal tissues studied, but an increase in the EGF concentration in the female tissues. Previous studies on the effect of gonadectomy or sialoadenectomy, or both, on the EGF concentration in the plasma, submandibular gland, kidney, and other tissues have been performed, but there is no information about the effect of gonadectomy on the EGF concentration in the gastrointestinal tract. Tuomela et al, showed that after gonadectomy, female mice had a 2.5 fold higher concentration in the submandibular gland than males in contrast to 4.5 times as much EGF in intact males. ${ }^{8}$ This agrees with our results. Other researchers found that the EGF concentrations in the submandibular gland of oophorectomised mice were higher than in controls, but still less than in intact male mice. ${ }^{5}$ This is also consistent with our findings as shown in Figure 2. Orchidectomy with sialoadenectomy led to a fall in the EGF concentration in the gastrointestinal tract of both sexes. However, the most significant effect was noticed in the stomach. The changes in the colon and to a smaller extent in the small intestine were less marked.

Orchidectomy led to total body weight decrease, as well as a significant decrease in the weight and the protein concentration of the submandibular gland, but it had no significant effect on the weight of other gastrointestinal tissues in male mice. These effects could possibly result from withdrawal of the anabolic effect of androgens after orchidectomy, and their regulatory interaction with gonadotropins from the anterior pituitary gland. Oophorectomy, however, did not lead to a change in total body or tissue weights, and it did not cause any alteration in the protein concentration of gastrointestinal tissues. There was little difference between the weights of submandibular glands in the gonadectomised mice of both sexes. These results agree with those of Tuomela $e t a l^{78}$ who reported that gonadectomy caused a decrease in the weight of male mice while there was no effect on the weight of female mice ${ }^{812}$ and showed that sialoadenectomy caused $55 \%$ less weight gain 
than that seen in sham operated female adult mice. We performed sialoadenectomy in addition to gonadectomy, however, and cannot state the effect of sialoadenectomy alone on body weight. In general, gonadectomy with sialoadenectomy did not show any additional effect to that of gonadectomy alone on the protein concentration, tissue, and total body weight, but it did have a significant effect on the EGF concentration in different gastrointestinal tract tissues. However, it is of interest that orchidectomy plus sialoadenectomy resulted in a large increase in the protein concentration in male mouse colon $(\mathrm{p}<0.02)$ compared with values in 11 week sham operated controls (Table I). This increase remains as yet unexplained.

The large difference in the EGF concentration of the salivary gland between male and female mice is not entirely explained and many hypotheses have been suggested. There may be a differential sensitivity of the gastrointestinal cells to the sex hormones and it is known that androgens can inhibit cell production in the gastrointestinal tract. ${ }^{13}$ It may be that the higher concentrations of luminal EGF in the male mice are needed to counteract the inhibitory effects of endogenous androgens. Since androgens are known to stimulate increased EGF concentrations, the initiation of their action is either directly with the androgen receptor or indirectly after biotransformation, but the stimulatory effect of progestins on submandibular gland EGF has been shown to be through the androgen receptor only..$^{14} 15$

The granular convoluted tubule cells of male mice submandibular glands contain greater amounts of EGF-mRNA than those in females. ${ }^{16}$ The concentration of EGF-mRNA in the submandibular gland of male mice decreased rapidly and remarkably after castration, while the EGF concentration decreased much more slowly. Three weeks after castration the EGF-mRNA concentration in males was found to be intermediate between values in intact males and females indicating the effects of androgens on EGF synthesis are rather prolonged. By contrast, castrated males treated with androgens or intact mice treated with $\mathrm{T}_{3}$ showed a high EGF-mRNA concentration indicating a relatively rapid induction of EGF-mRNA by both hormones. ${ }^{17}$ These conclusions are consistent with a very rapid and pronounced decrease in EGF gene transcription caused by testosterone depletion after castration. ${ }^{11}$ Epidermal growth factor itself may affect the function of a variety of endocrine systems, modulating hormone production from adrenal, gonad, thyroid, placenta, and several hypothalamic and pituitary sources. ${ }^{18}$

In conclusion, we found that the immunoreactive EGF concentration in the gastrointestinal tissues is altered by gonadectomy.
Sialoadenectomy combined with gonadectomy led to a decrease in the EGF concentration in the gastrointestinal tract of both sexes. The importance of the gonads and their hormonal effects on EGF metabolism or secretion in different tissues of the gut is quite profound, and these effects as well as the origin of EGF in the gut, need to be explored further.

We thank Dr H Gregory, formerly of ICI, for his gift of mouse EGF and his help and encouragement, Dr M Thorniley, MRC London, for her help and advice, Dr P Jones, Department of Mathematics, Keele University for his assistance in the statistical analysis. This work was presented in part to the British Society of Gastroenterology and published as an abstract: Gut 1992; 33: F256.

1 Byyny RL, Orth DN, Cohen S. Radioimmunoassay of epidermal growth factor. Endocrinology 1972; 90: 1261-6.

2 Bullock LP, Barthe PL, Mowszowicz I. Orth DN, Bardin $\mathrm{CW}$. The effect of progestins on submandibular gland epidermal growth factor: demonstration of androgenic, syndrogenic and antiandrogenic actions. Endocrinology 1975; 97: 189-95.

3 Gresik EW, Schenkein I, Van der Noen H, Barka T. Hormonal regulation of epidermal growth factor and protease in the submandibular gland of adult mouse. protease in the submandibular
Endocrinology 1981; 109: 924-9.

4 Walker P, Weischel ME, Hoath SB, Poland RE, Fisher DA. Effects of thyroxin, testosterone and corticosterone on nerve growth factor (NGF) and epidermal growth factor (EGF) concentration in adult female mouse submandibular gland: dissociation of NGF and EGF responses. Endocrinology 1981; 109: 582-7.

5 Kurachi H, Oka T. Regulation of the concentration of epidermal growth factor by oestrogen in the submandibular gland of female mice. 7 Endocrinol 1986; 109: 221-5.

6 Byyny RL, Orth DN, Cohen S, Doyle E. Epidermal growth factor: Effect of androgen and adrenergic agents. Endocrinology 1974; 95: 776-82.

7 Tuomela T, Viinika L, Perheentupa J. Effects of oestradiol and progesterone on epidermal growth factor concentration in plasma, bile, urine, submandibular gland and kidney of the mouse. Horm Res 1989; 31: 143-7.

8 Tuomela T, Miettinen P, Pesonen K, Viinika L, Perheentupa J. Epidermal growth factor in mice: Effects of oestradiol, testosterone and dexamethasone. Acta Endocrinologica 1990; 123: 211-7.

9 Steidler NE, Reade PC. An immunohistochemical and histological study of the influence of the testes and adrenal glands on epidermal growth factor-concentrating cells in the submandibular salivary glands of male mice. $\mathcal{F}$ Anat 1982; 135: 413-21.

10 Bradford M. A rapid and sensitive method for the quantitation of microgram quantities of protein, utilizing the principle of protein dye binding. Anal Biochem 1976; 72: ciple of

11 Pascall JC, Sanders J, Blakeley DM, Laurie MS, Brown $\mathrm{KD}$. Tissue specific effects of castration and ovariectomy on murine epidermal growth factor and its mRNA. f Endocrinol 1989; 121: 501-6.

12 Perheentupa J, Lakshmanan J, Hoath SB, Fisher DA. Hormonal modulation of mouse plasma concentration of epidermal growth factor. Acta Endocrinol 1984; 107: 571-6.

13 Mori M, Naito R, Tsukitani K, Okada Y, Tsujimura T. Widespread distribution of human epidermal growth factor (h-EGF) in human tissues and organs under normal and tumorous conditions - immunohistochemical studies with the use of polyclonal and monochemical studies with the use of polyclonal and monoclonal ant 34 .

14 Bullock LP, Barthe PL, Mowszowicz I. Orth DN, Bardin $\mathrm{CW}$. The effect of progestins on submandibular gland epidermal growth factor: demonstration of androgenic, syndrogenic and antiandrogenic actions. Endocrinology 1975; 97: 189-95.

15 Welsh TH, Hsueh AJW. Mechanism of inhibitory action of epidermal growth factor on testicular androgen vitro. Endocrinology 1982; 110 Scott J, Urdea M, Quiroga M, Sanchez-Pessador R, Fong $\mathrm{N}$, Selby $\mathrm{M}$, et al. Structure of mouse submaxillary messenger RNA encoding epidermal growth factor

17 Gresik EW, Gubits RM, Barka T. In situ localisation of mRNA for epidermal growth factor in the submandibular gland of the mouse. F Histochem Cytochem 1985; 33: 1235-40.

18 Fisher DA, Lakshmanan J. Metabolism and effects of epidermal growth factor and related growth factors in mammals. Endocr Rev 1990; 11: 418-42. 